\title{
Perspectives of the legislation on the Red Book of Ukraine development
}

\author{
(1) Olexiy Vasyliuk ${ }^{1,2}$
}

\author{
${ }^{1}$ Ukrainian Nature Conservation Group, Gogol str. 40, 08600 Vasylkiv, Kyiv region, Ukraine; vasyliuk@gmail.com \\ 2 Department of Monitoring and Protection of the Animal World, I. I. Schmalhausen Institute of Zoology, National Academy of Sciences \\ of Ukraine, Bohdana Khmelnytskoho str. 15, 01030 Kyiv, Ukraine
}

Received: 20.10 .2020 | Accepted: 12.11 .2020 | Published: 30.12 .2020

\begin{abstract}
The principal legislative document regulating the protection of the plants and animal species in Ukraine is the Law of Ukraine "On the Red Book of Ukraine". However, Ukrainian legislation related to the Red Book of Ukraine (RBU) is not agile. It does not react to the modern challenges and does not operate by new opportunities provided, for example, through the Law "On Environmental Impact Assessment". Environmental impact assessments (EIA) are required for many management activities, including woodcutting, mining, and melioration, and should protect the environment. On the other side, unfortunately, the section "Impact on flora and fauna" in EIA reports often prepared superficially and formally. This section usually does not contain real research results and does not offer real measures for the protection of endangered species. Since today, there are no known cases when the EIA report was issued considering the real conservation needs of the species listed in the RBU.

This letter proposes introducing several amendments to the legislation on the RBU, which are required for its integration into the EIA. First, it is proposed to introduce individual protection requirements for each species included in the RBU, which will allow the implementation of appropriate environmental conditions in the EIA conclusions. Secondly, it is proposed to introduce the responsibility for conserving species for users and owners of sites where coenopopulations, individuals (for plants), or permanent habitats (for animals) of the RBU species are located. Third, it is proposed to introduce a mechanism for documenting the location of the RBU species. These changes would make it possible to identify specific legal entities and individuals for whom species protection obligations and the penalties for disturbance will be imposed.
\end{abstract}

Keywords: Red Book of Ukraine, environmental impact assessments, biodiversity protection, ecological legislation

The Red Book of Ukraine (RBU) is the principal list of protective species in Ukraine. Only for the species listed in the RBU the Ukrainian legislation provides a wide range of protection options, as well as fees and methods of calculating the damages caused to the state by the destruction of such species or their habitats.

At the same time, environmental impact assessment (EIA), which integrates the European mechanism for the preliminary assessment of the possible impact of planned activities on the environment's components, including rare species, has recently become widespread. Unfortunately, the section "Impact on flora and fauna" in the EIA reports usually is superficial and formal. It lacks the results of real research and does not propose real measures to protect specific species that may be adversely affected. This EIA is obligatory for many activities, including woodcutting, mining, melioration, and other managements, which together represent the vast majority of anthropogenic impacts on biodiversity. 
EIA's requirement could increase biodiversity studies and promote local conservation measures, at least for RBU species. However, many legislation imperfections make the real protection of RBU species ineffective.

\section{The lack of protection requirements}

The principal law regulating the protection of the plants and animal species in Ukraine is the Law of Ukraine "On the Red Book of Ukraine". Basing on this law, the species are included in the RBU gain their protective status and specific penalties for their destruction. From the 70,000 living organism known to Ukraine, the RBU comprises 826 plant and fungi species and 542 animal species in total.

According to Art. 12 of the Law "On Environmental Protection", Ukraine citizens are obliged to care for, protect, and rationally use natural resources. However, in context of the protective measures for the RBU species, they are mentioned only in the RBU. For example, in the RBU, it is indicated that Lilium martagon L. disappears due to deforestation, as it needs partial shading; hence, it is forbidden to collect the plants and cut down forests (Andriyenko, 2009). Similarly, RBU says that all types of reclamation works, peat development are prohibited for the conservation of Lycopodium inundatum L. (Priadko, 2009). Individual protective requirements are also indicated for all other species listed in the RBU. However, they are not mentioned in any legislation document, and therefore are not obligatory. In other words, Ukrainian legislation says that it is necessary to protect the species listed in the RBU but does not say how exactly. Similarly, the activity restrictions required for the RBU species preservation are also not legislated.

The protection requirements for RBU species should be differentiated, as they inhabit different habitats and biotopes, are unequally exposed to negative influences in different seasons, and have different suppression factors. Along with general protection measures, such requirements should also embrace particular threats, certain plants' growth conditions, conservation regimes, and regional nature peculiarities. It is also essential to protect RBU species integrally to their habitats since most cases, especially the plant species, require complex habitat preservation. Such concept of species protection, taking into account their peculiarities and habitats, should significantly improve the RBU legislation and bring it close to the international environmental legislative acts such as the Convention on the Conservation of European Wildlife and Natural Habitats (Berne Convention), as well as to the principles of forest certification according to FSC standards. Moreover, in case of the introduction of individual requirements for protecting certain species to Ukrainian legislation, it will be possible to include such requirements in EIA.

\section{Protection objects and subjects}

The Law of Ukraine "On the Red Book of Ukraine" makes provision for protecting the rare species. However, it does not state who exactly should protect them. The service, which would continuously protect the RBU species, is absent. The law does not provide any mechanism of protection of such species. As a result, many natural areas are managed without considering the presence of endangered species and without paying attention to the restrictions. Moreover, if considering that information about the presence of the RBU species on certain areas is absent, any activity can potentially harm them, and we even will not know about this. Nevertheless, it is not easy to imagine the whole country's biota survey and inventory by specialists from all taxonomic groups. Similarly, it looks not possible to create some institution that could regularly monitor the condition of all sites with RBU species (Kostushin, 1993).

Thus, if not possible to create a superior authority for the protection and monitoring of RBU species, the solution will probably impose this responsibility on the landowners and users. This can be achieved by implementing the protection obligations similar to those for the nature conservation areas. It is also important to introduce mandatory surveys of the area by scientists in the area's management changes and before new activities on the area with the RBU species' known presence. The land users are the main subjects influencing flora and fauna (including RBU species), and therefore, the introduction of protection obligations would be a logical and practical mechanism of nature conservation. Among other things, such protection obligations should become a 
limiting factor for changes in the land purpose and should be inherited by the new land user in case of change. Considering that in most cases the subject of EIA is a land user, the protection obligations could become a part of the environmental requirements for the EIA conclusions. Moreover, the legislation basis of the introduction of the protection obligations is explained in Art. 34 of the Law of Ukraine "On the animal world".

\section{Registering the species findings}

RBU is the only protection list in Ukraine, stipulating penalties in case of harm caused to the RBU species. However, there is no procedure for detecting and registering such species, according to which such penalties could be implemented. Even scientific articles in academic journals are not legal proof (e.g., in the court) of RBU species' presence on particular territory before it was destroyed. Hence, it is expedient to introduce detection and registration of the RBU species before possible negative influence, at the stage of approval of documentation on land allocation, provision of plots for use or sale, change of their, construction and approval of other measures and actions that may adversely affect RBU species, such as forestry, felling, etc. Such an idea is argued by a) the inability to quickly inventory the entire Ukraine territory; b) the priority given to the areas where negative impacts are predicted; c) the inventory of RBU species by scientists can be included as a required part of the EIA procedure.

An example of applying the information on the distribution of RBU species is the EIA procedure at the Boyarka Forest Research Station (Kyiv region), which took place in 2020. The EIA report allowed continuous and selective felling in old forests on more than 8,000 hectares. However, the local organization "Development and Landscaping" and the Homilsha Woods National Nature Park invited scientists who mapped RBU species on this area. After that, the survey report showing that only limited wood cuttings can be realized in this territory was submitted to the Ministry of Environment of Ukraine and the land user. As a result, the Ministry of Environment of Ukraine did not consider the EIA report and did not allow felling activities in this area.

During its existence, since 2009, the Law of Ukraine "On the Red Book of Ukraine" has only been amended five times (and changes mostly concerned only some parts of it). For example, during the same period, the Law of Ukraine "On Nature Reserves Fund" has been amended 15 times, and the volume of these changes is close to the entire law "On the Red Book of Ukraine". This illustrates the sluggishness of the RBU legislation. It is non-dynamic, does not respond to modern challenges, and does not use new opportunities, such as the introduction of EIA. We believe that the RBU legislation needs to be changed, and here only some of the priority changes were outlined.

\section{References}

Andriyenko, T. L. (2009). Lisova liliya. Lilium martagon L. (p. 141). In Y. P. Didukh (Ed.), Red Book of Ukraine. Kyiv: Globalconsulting.

Priadko, O. I. (2009). Plaunets zaplavniy. Lycopodiella inundata (L.) Holub. (p. 17). In Y. P. Didukh (Ed.), Red Book of Ukraine. Kyiv: Globalconsulting.

Kostushin, V. A. (1993). About the project of the state service for monitoring the species of fauna and flora of Ukraine, which are under the protection of the law. Oikumena, 3, 69-70.

\section{Перспективи розвитку законодавства про Червону книгу України}

Олексій Василюк ${ }^{1,2}$

\footnotetext{
1 Українська природоохоронна група, вул. Гоголя, 40, Васильків, Київська область, 08600, Україна; vasyliuk@gmail.com

2 Відділ моніторингу та охорони тваринного світу, Інститут зоології ім. І.І. Шмальгаузена НАН України, вул. Богдана Хмельницького, 15, Київ, 01030, Україна
} 
Базовим законом, що врегульовує в Україні питання охорони видів як рослинного, так і тваринного світу, $\epsilon$ Закон України “Про Червону книгу України”. Але законодавство про Червону книгу України (ЧКУ) $\epsilon$ нединамічним та не реагує на сучасні виклики, а також не використовує нові можливості, такі як, наприклад, появу Закону “Про оцінку впливу на довкілля" (ОВД). ОВД стосується багатьох сфер діяльності, зокрема рубок лісів, видобування корисних копалин, меліорації та інших видів діяльності. На жаль, зазвичай розділи "вплив на флору і фауну" в звітах з ОВД також пишуть поверхнево і формально. У них відсутні результати реальних досліджень, а також не пропонуються реальні заходи з охорони конкретних загрожуваних видів. На сьогодні практично не відомо, щоб висновки ОВД видавались із урахуванням потреб збереження видів, внесених до ЧКУ.

У статті пропонується запровадити низку змін до законодавства про ЧКУ, необхідних у зв'язку із необхідністю інтегрувати ЧКУ у процес оцінки впливу на довкілля. По-перше, пропонується запровадити індивідуальні вимоги охорони для кожного з видів ЧКУ, що дасть змогу передбачати відповідні екологічні умови у висновках ОВД. По-друге, пропонується передбачити відповідальність за збереження видів для користувачів і власників ділянок, на яких розташовані ценопопуляції, особини (для рослин) або постійні оселища (для тварин) видів ЧКУ. По-третє, пропонується запровадити механізм документування місцезнаходжень видів ЧКУ. Ці зміни дозволять ідентифікувати конкретних юридичних і фізичних осіб, щодо яких будуть передбачені зобов'язання охорони видів і відповідальність за недотримання умов їх охорони.

Ключові слова: Червона книга України, оцінка впливу на довкілля, охорона біорізноманіття, екологічне законодавство 